\title{
$\alpha$-Glucosidase Inhibitory and Antiradical Properties of Acacia macrostachya
}

\author{
Hamidou Têeda Ganamé, Yssouf Karanga, Ousmane Ilboudo, Wende-Konté Hazael Conania Nikiema, \\ Richard Wamtinga Sawadogo, Issa Tapsoba
}

\section{ABSTRACT}

In this work, the anti-diabetic activity of three extracts of Acacia macrostachya was investigated by following the inhibitory effect of these extracts on $\alpha$ glucosidase using the in vitro model. The antiradical activity of these extracts was also determined. Methanol extracts of root and stem barks showed a very significant inhibitory effect against the enzyme activity of $\alpha$-glucosidase with IC $\mathrm{C}_{50}$ $2.487 \pm 0.441 \mu \mathrm{g} / \mathrm{mL}$ and $1.650 \pm 0.229 \mu \mathrm{g} / \mathrm{mL}$ respectively. For antiradical activity, the same extracts presented the highest scavenging of the radical DPPH ${ }^{\bullet}$ with IC 50 values of $9.307 \pm 0.262 \mu \mathrm{g} / \mathrm{mL}$ and $5.242 \pm 0.068 \mu \mathrm{g} / \mathrm{mL}$ respectively. With the cationic radical $\mathrm{ABTS}^{\bullet+}$, $^{\mathrm{IC}_{50} \text { varied from } 45.049 \pm 0.730 \mu \mathrm{g} / \mathrm{mL} \text { for }}$ methanolic root barks extract to $14.136 \pm 0.161 \mu \mathrm{g} / \mathrm{mL}$ for methanolic extract from stem barks. Thus, the methanol extracts of the root and stem barks of Acacia macrostachya possess compounds with very interesting anti-diabetic and antiradical properties and could justify its traditional use.

Keywords: Acacia macrostachya; Antiradical Activity; Diabetes; $\alpha$ Glucosidase.

Published Online: September 18, 2020

ISSN: $2593-8339$

DOI: $10.24018 /$ ejmed.2020.2.5.465

Hamidou Têeda Ganamé

Laboratoire de Chimie Analytique Environnementale et Bio-organique (LCAEBiO), Université Joseph KIZERBO, Ouagadougou, Burkina Faso.

Yssouf Karanga

Laboratoire de Chimie Analytique Environnementale et Bio-organique (LCAEBiO), Université Joseph KIZERBO, Ouagadougou, Burkina Faso; Laboratoire de Chimie des Matériaux et de l'Environnement, (LCME), Université Norbert ZONGO, Koudougou, Burkina Faso

Ousmane Ilboudo

Laboratoire de Chimie Analytique Environnementale et Bio-organique (LCAEBiO), Université Joseph KIZERBO, Ouagadougou, Burkina Faso. Wende-Konté Hazael Conania Nikiema Laboratoire de Chimie Analytique Environnementale et Bio-organique (LCAEBiO), Université Joseph KIZERBO, Ouagadougou, Burkina Faso. Richard Wamtinga Sawadogo Institut de Recherche en Science de la Santé (IRSS/CNRST), Ouagadougou, Burkina Faso

Issa Tapsoba*

Laboratoire de Chimie Analytique Environnementale et Bio-organique (LCAEBiO), Université Joseph KIZERBO, Ouagadougou, Burkina Faso.

(e-mail: issa.tapsoba ${ }^{@}$ gmail.com)

*Corresponding Author

\section{INTRODUCTION}

Diabetes is a disease that is invading our planet and constitute a major concern for global health services. It is a scourge that is spreading both in developed and developing countries at an alarming rate. In fact, 382 million people had diabetes in 2013 and this number could reach 592 million by 2035 according to the forecasts of the International Diabetes Federation [1]. Diabetes is a chronic disease characterized by permanent hyperglycemia with fasting blood glucose levels of $1.26 \mathrm{~g} / \mathrm{L}$ on two occasions and/or greater than $2 \mathrm{~g} / \mathrm{L}$ at any time of the day [2]. Two types of diabetes are commonly known: one is insulin-dependent diabetes (type 1) and the other is non-insulin-dependent diabetes (type 2) [3]. Type 1 diabetes is treated by regular injections of insulin. Type 2 diabetes is the most common and accounts for more than $90 \%$ of diabetes cases [3]. Otherwise, one of the direct complications associated with hyperglycemia has been shown to be cancer. Diabetes mellitus (type 2) is a chronic, often debilitating disease with severe complications, 
including blindness, heart disease, kidney disease and refract neuropathy [4]-[6]. It is found in almost all populations and appears to be a growing problem in developing countries. It is mainly due to insulin resistance and is associated with lifestyle, obesity, malnutrition and physical inactivity. Treatment of this type of diabetes is not easy especially since it is not insulin-dependent [7]. Nevertheless, maintenance of glucose levels in healthy blood has been shown to be particularly important in the management of people with type 2 diabetes [8]. The first-line treatment for type 2 diabetes is diet, weight control and physical activity [3]. Several categories of anti-diabetic drugs are also available, including $\alpha$-glucosidase inhibitors. $\alpha$-Glucosidase is a key enzyme in the digestive system and catalyzes the first step in the digestion of starch, hydrolyzing the $\alpha$-1,4-glucoside linkages [3]. In fact, the hydrolysis of dietary carbohydrates such as starch is the major source of glucose in the blood. Inhibition of this enzyme would significantly lower blood sugar levels and help maintain a good blood sugar level. In addition, it has also been shown that diabetic patients are under oxidative stress leading to the generation of free radicals and antioxidant deficiency that may contribute to the onset and progression of complications associated with diabetes [9]. Therefore, the use of antioxidants by diabetic patients is particularly important not only to maintain the balance between the free radicals generated and the trapping abilities of radicals but also to treat long-term complications that may occur [10]. Like other sub-Saharan countries, Burkina Faso has not been left on the sidelines of this disease. Indeed, in 2013 its prevalence rate was $4.9 \%$ among the population aged 25 to 64 years [11].

The burden of diabetes continues to grow globally, putting considerable physical, emotional and financial pressure on individuals, families, communities and health systems [12]. Many health systems in low- and middle-income countries are least prepared to deal with this burden, resulting in thousands of deaths each year. Indeed, $87 \%$ of all diabetes related to those countries [13]. Among these countries is Burkina Faso, which is also facing the emergence of diabetes mellitus due to the precarious conditions of patient care and socio-economic indigence. The majority of the population, which does not have adequate health coverage, relies mainly on local medicinal plants for their primary health care. In these countries, more than $80 \%$ of people most often use traditional medicine for primary health care [14]. Local and international institutions such as WHO encourage and support the use of these therapeutic plants, which are often highly effective and accessible to all. This is the case of Acacia macrostachya (Mimosaceae), a medicinal plant widely used in Burkina Faso and widely used by therapists against certain pathologies such as inflammation, cancer and oxidative stress [15]-[17]. Some works previously done on the leaf and root extracts of this plant has revealed the presence of flavonoids, tannins, terpenoid, alkaloids, saponins and steroids [15], [17], [18]. In addition, some authors have reported in the literature that methanol and dichloromethane extracts from the plant had significant antioxidant activities [15], [17]. More interestingly, many studies have shown good correlation between antioxidant activity and antidiabetic properties of some plant extracts. The present study aims to evaluate the antiradical and antidiabetic activities of extract of Acacia macrostachya.

\section{MATERIAL AND Methods}

\section{A. Vegetable material}

The plant material was constituted of the root and stem barks of Acacia macrostachya. They were collected in February 2018 at about twenty kilometers of Ouagadougou, Burkina Faso with GPS coordinates 12 $31^{\prime} 50,52^{\prime \prime} \mathrm{N}$; $01^{\circ} 17^{\prime} 2,7^{\prime \prime} \mathrm{W}$ and a voucher specimen was deposited at the herbarium of University Joseph KI-ZERBO (identification number 17252). The vegetable material was, moreover, transformed into fine powder using an electric grinder after two (02) weeks of drying at the laboratory temperature and under ventilation. Then, $50 \mathrm{~g}$ of the powder were macerated in the appropriate solvent (dichloromethane or methanol) for 24 hours under magnetic agitation. After filtration, the macerated is evaporated to dry using a rotary evaporator (BÜCHI Rotavapor R-200). We prepared total three types of extract: dichloromethane extract from root barks (RB1), methanolic extract from root barks (RB2) and methanolic extract from stem barks (SB3).

\section{B. Reagents}

$\alpha$-Glucosidase, $\quad$ p-nitrophenyl- $\alpha$-D-glucopyranoside (PNPG), acarbose (antihyperglycemic reference drug) and Trolox were provided from Sigma-Aldrich. Anhydrous sodium carbonate $\left(\mathrm{Na}_{2} \mathrm{CO}_{3}\right)$ solution, DPPH and ABTS reagents and all other reagents used in this work were prepared at the laboratory according to standard protocol.

\section{C. $\alpha$-Glucosidase inhibition assay}

The inhibitory effect of the enzyme $\alpha$-glucosidase of the extracts was assessed using the chromogenic method reported by Ranilla and al. [19] with slight modifications. The assay was carried out in 96 well plates with the maximum volume of $250 \mu \mathrm{L}$ per well. Indeed, the reaction was initiated by mixing $20 \mu \mathrm{L}$ of the enzyme $\alpha$-glucosidase (0.5 units $/ \mathrm{mL}), 10 \mu \mathrm{L}$ sample at different concentrations and $120 \mu \mathrm{L}$ of phosphate buffer ( $0.1 \mathrm{M}$; pH 6.9). After 15 minutes of pre-incubation at $37^{\circ} \mathrm{C}$, the enzymatic reaction was initiated by adding $20 \mu \mathrm{L}$ of p-nitrophenyl- $\alpha$-Dglucopyranoside $(5 \mathrm{mM}$ prepared in a phosphate buffer $0.1 \mathrm{M}$; pH 6.9). The mixture was incubated during 15 new min, still at $37{ }^{\circ} \mathrm{C}$. The reaction ended adding $80 \mu \mathrm{L}$ of sodium carbonate solution $(0.2 \mathrm{M})$. The inhibitory activity of $\alpha$-glucosidase was determined by measuring the absorbance of p-nitrophenol released by p-nitrophenyl- $\alpha-D$ glucopyranoside at $405 \mathrm{~nm}$ by a spectrophotometer (SPECTROstar NANO, BMG LABTECH, Ortenberg, Germany). Positive control was the reaction mixture without the inhibitory substance and the system without $\alpha$ glucosidase was used as blank for correcting the background absorbance. The inhibition percentage was calculated by the following equation:

$$
\% \text { of inhibition }=\frac{\text { Abs control }- \text { Abs sple }}{\text { Abs control }} \times 100
$$


Abs control: absorbance control

Abs sple: absorbance sample

\section{D. $D P P H^{\bullet}$ and $A B T S^{\bullet+}$ radial scavenging assay}

$\mathrm{DPPH}^{\bullet}$ and $\mathrm{ABTS}^{\bullet+}$ are two stable free radicals marketed and widely used in the evaluation of antiradical activity of any plant extract. Faced to an antiradical substance, these two radicals initially purple and green respectively for $\mathrm{DPPH}^{\bullet}$ and $\mathrm{ABTS}^{\bullet+}$ turn to yellow or fade (respectively for $\mathrm{DPPH}^{\bullet}$ and $\mathrm{ABTS}^{\bullet+}$ ) reflecting an antiradical activity of the extract. In this work, the antiradical activity of the three extracts of Acacia macrostachya was assessed in vitro model by measuring the different optical densities of the two radicals after they were exposed to the toxic substances. For the measurement, $50 \mu \mathrm{L}$ of each extract in methanol (different concentrations) are added $200 \mu \mathrm{L}$ of the radical $\mathrm{DPPH}^{\bullet}$ or the cationic radical $\mathrm{ABTS}^{\bullet+}$ solution in methanol. After 10 min of incubation away from the light, the absorbances of the discoloration of the reaction mixture are read at $517 \mathrm{~nm}$ and $700 \mathrm{~nm}$ respectively for the radicals $\mathrm{DPPH}^{\bullet}$ and $\mathrm{ABTS}^{\bullet+}$. The Trolox was used as standard. The control contained 50 $\mu \mathrm{L}$ of methanol with $\mathrm{DPPH}^{\bullet}$ or $\mathrm{ABTS}^{\bullet+}$ and the blank contained methanol without $\mathrm{DPPH}^{\bullet}$ or $\mathrm{ABTS}^{\bullet+}$ radical solution. The $\mathrm{IC}_{50}$, expressed in $\mu \mathrm{g} / \mathrm{mL}$, were determined using the equations of the calibration curves of each sample. The $\mathrm{IC}_{50}$ is the value of the concentration of the extract that would trap $50 \%$ of the radicals. The lower is this value, the better is the radical activity of the extract.

\section{E. Statistical analysis}

All experiments were repeated three times $(n=3)$ and results are expressed as mean \pm standard deviation (SD) of
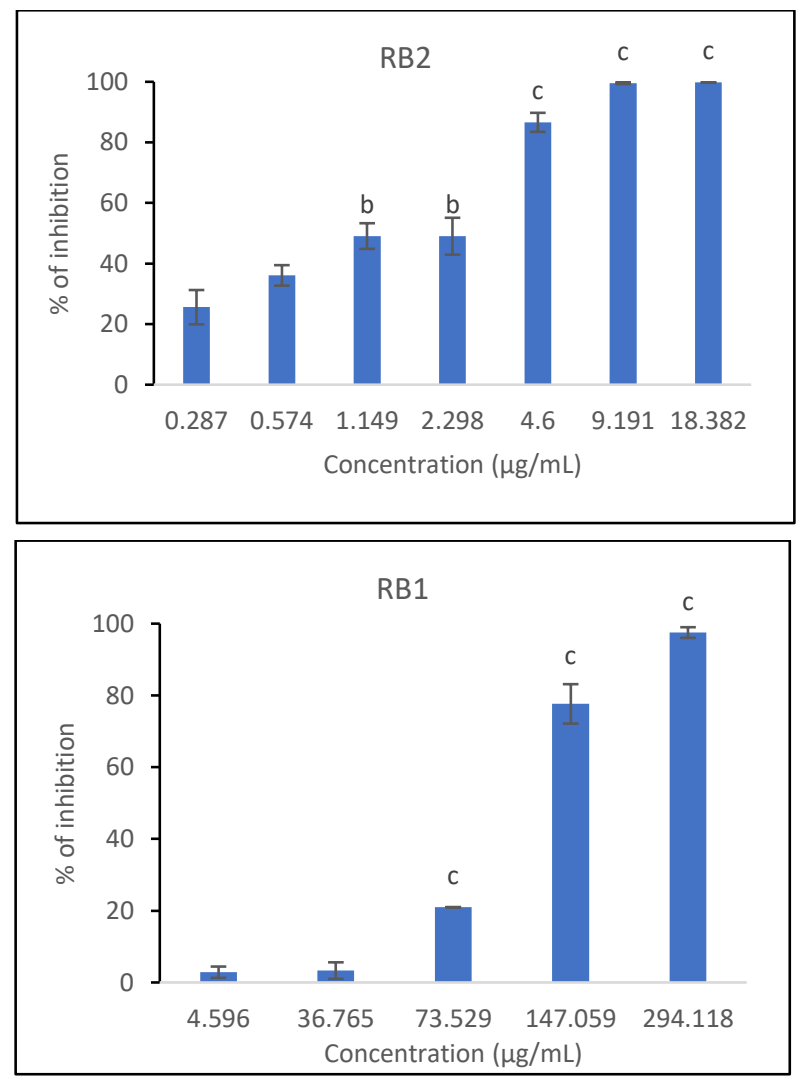

Fig. 1. Inhibitory activities of extracts of the root and stem barks of Acacia macrostachya and acarbose (positive control compound)) against $\alpha$ glucosidase activity. Values are given as the mean \pm SD of three independent assays. Data were analyzed using ANOVA followed by XLSTAT. Values

were considered statistically significant at $\mathrm{p}<0.05 ; \mathrm{b}: \mathrm{p}<0.001 ; \mathrm{c}: \mathrm{p}<0.0001$.

the experiments. Statistical significance was evaluated by one-way analysis of variance (ANOVA) using XLSTAT version 16.0 (Addinsoft (2020) XLSTAT statistical and data analysis solution. Paris France). Values were considered statistically significant at $\mathrm{p}<0.05$. The $\mathrm{IC}_{50}$ values were determined by plotting the calibration curve of the percent of inhibition according to concentrations.

\section{RESULTS}

\section{A. $\alpha$-Glucosidase inhibition}

In this work, the inhibitory effect of $\alpha$-glucosidase of three extracts of Acacia macrostachya was assessed. To recall, $\alpha-$ glucosidase is a key enzyme linked to type 2 diabetes. The obtained results are shown on the histograms below (Fig. 1). It is clear from these histograms that all extracts have an inhibitory effect on the enzymatic activity of $\alpha$-glucosidase. According to the results, the activity of the extracts is dosedependent and appears to be more pronounced with SB3 in regard to the inhibition rate depending on the concentration, which reach $94 \%$ at $2.298 \mu \mathrm{g} / \mathrm{mL}$, while the other extracts, at the same concentration, have moderate inhibitory activity. To confirm this hypothesis, $\mathrm{IC}_{50}$ values were determined and recorded in Table 1. It is apparent from this table that all the extracts mentioned are more active than the acarbose used as a reference anti-diabetic drug.

\begin{tabular}{|c|c|c|c|c|}
\hline Extracts & RB1 & RB2 & SB3 & Acarbose \\
\hline $\begin{array}{c}\mathrm{IC}_{50} \\
(\mu \mathrm{g} / \mathrm{mL})\end{array}$ & $\begin{array}{l}138.485 \\
\pm 5.649\end{array}$ & $\begin{array}{c}2.487 \\
\pm 0.441\end{array}$ & $\begin{array}{l}1.650 \\
\pm 0.229\end{array}$ & $\begin{array}{l}214.830 \\
\pm 3.816\end{array}$ \\
\hline
\end{tabular}
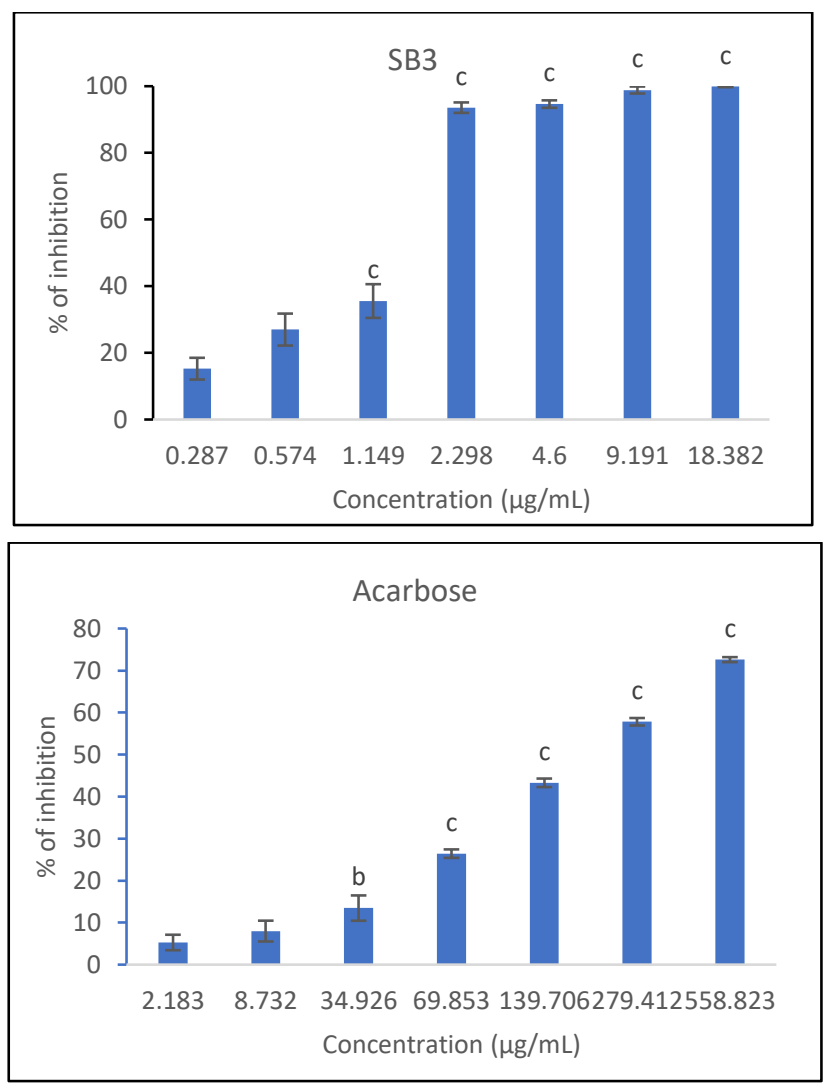


\section{B. $\mathrm{DPPH}^{\bullet}$ and $\mathrm{ABTS}^{\bullet+}$ radicals scavenging assay}

The antiradical properties of the different extracts were evaluated according to the protocol described above. The results are reported in Table 2. It appears that all extracts showed antiradical activity, the best activities are those from methanol extracts (RB2 and SB3) from the root barks and stem of Acacia macrostachya. Indeed, SB3 strongly inhibited the radical activity of the two free radicals with $\mathrm{IC}_{50}$ values of $5.242 \pm 0.068 \mu \mathrm{g} / \mathrm{mL}$ and $14.136 \pm 0.161 \mu \mathrm{g} / \mathrm{mL}$ respectively by the DPPH and the ABTS test followed by RB2 $(9.307 \pm 0.262 \mu \mathrm{g} / \mathrm{mL}$ and $45.049 \pm 0.730 \mu \mathrm{g} / \mathrm{mL}$ respectively). RB1 has the lowest antiradical activity with an $\mathrm{IC}_{50}$ of $539.362 \pm 7.251 \mu \mathrm{g} / \mathrm{mL}$. The values of antiradical activity on the radical $\mathrm{DPPH}^{\bullet}$ were found to be more important for all extracts.

TABLE 2: IC $_{50}(\mu \mathrm{G} / \mathrm{ML})$ VALUES OF ANTI-RADICAL ACTIVITY OF DIFFERENT EXTRACTS AND TROLOX

\begin{tabular}{ccc}
\hline \multirow{2}{*}{ Extracts } & \multicolumn{2}{c}{$\mathbf{I C}_{\mathbf{5 0}}(\boldsymbol{\mu g} / \mathbf{m L})$} \\
\cline { 2 - 3 } & $\mathbf{D P P H}$ & $\mathbf{A B T S}$ \\
\hline RB1 & $539.362 \pm 7.251$ & $\mathrm{ND}$ \\
\hline RB2 & $9.307 \pm 0.262$ & $45.049 \pm 0.730$ \\
\hline Trolox & $5.242 \pm 0.068$ & $14.136 \pm 0.161$ \\
\hline \hline
\end{tabular}

ND: Not Determined

\section{DISCUSSION}

The results of the inhibitory effect show that all the extracts significantly inhibit the enzymatic activity of $\alpha$ glucosidase and are more active than the acarbose. This has been observed by other authors [3],[20]. The best activity of the extracts compared to the acarbose could be explained by a synergy of action of several molecules while acarbose intervenes through a single type molecule. Also, the molecules of the extracts would easily access the site attack of the enzyme unlike acarbose due steric hindrance. The methanol extracts (RB2 and SB3) showed a highest inhibitory effect against the enzyme $\alpha$-glucosidase with $\mathrm{IC}_{50}$ values of $2.487 \pm 0.441 \mu \mathrm{g} / \mathrm{mL}$ and $1.650 \pm 0.229 \mu \mathrm{g} / \mathrm{mL}$ respectively. RB1 showed also a significant inhibitory activity against the enzyme with an $\mathrm{IC}_{50}$ of $138.485 \pm 5.649$ $\mu \mathrm{g} / \mathrm{mL}$ compared to the reference substance (acarbose). There are several reports on the anti-diabetic activity of methanol extracts from medicinal plants. Indeed, Peyman and al. 2013 showed that the methanolic extracts of Darchin, Chay-e-makki, Tameshk (R. fruticous), Sorkhevalik, Qareqat and Toot (M. alba) strongly inhibited the activity of $\alpha$ glucosidase with $\mathrm{IC}_{50}$ values of $0.5 \pm 0.2,0.7 \pm 0.4,1.1 \pm 0.6$, $1.5 \pm 0.5,3.9 \pm 0.9$ and $8.9 \pm 1.0 \mu \mathrm{g} / \mathrm{mL}$ respectively [3]. Phytochemical screening revealed the presence of certain chemical groups including flavonoids, tannins, terpenoids/steroids and alkaloids in the extracts investigated [15]. The presence of these chemical groups could justify the results obtained on the inhibitory activity of $\alpha$-glucosidase. Indeed, phenolic compound (flavonoids and tannins) have been pointed out to be positively correlated with $\alpha$ glucosidase inhibitory activity [3]. These extracts with very interesting antidiabetic properties could therefore have a particular interest in prevention of the risk of developing cancer in diabetics. The relationship between diabetes and cancer is well established [21]. Indeed, epidemiological data have recently shown that the existence of type 2 diabetes promotes carcinogenesis [21], [22]. Specific management in diabetic patients is therefore necessary to avoid many complications with significant repercussions in terms of morbidity and mortality. One of the most common complications of diabetes is the onset of cancer. Numerous recent studies and meta-analyses have shown an association between diabetes and the occurrence of several types of cancer, including hyperglycemia [21], [23], [24]. So, the bioactive molecules contained in these extracts would be preventive molecules of the risk of excess mortality of diabetic patients by malignant tumors. They would also prevent the risk of several types of cancers (pancreatic, liver, colorectal, leukemia, lymphoma, etc.) in hyperglycemic patients. It has been demonstrated some oral antidiabetics, especially metformin, play a dual role: promotes patient management and reduces the risk of cancer [25]. In summary, current evidence suggests that diabetes increases the risk of several types of cancer.

$\mathrm{DPPH}^{\bullet}$ and $\mathrm{ABTS}^{\bullet+}$ radicals scavenging assay reveals that all extracts mentioned contain interesting antiradical properties. Ours previous studies have shown that the same extracts were rich in antioxidants with contents of $646.063 \pm$ $3.454 ; 422.748 \pm 6.045$ and $8.176 \pm 0.188 \mu \mathrm{g}$ Trolox equivalent per gram of extract respectively for SB3, RB2 and RB1. Then we notice that the radical scavenging effect of all samples was found to be stronger depending on the antioxidant content in the extract. It has been reported in the literature that antiradical activities are correlated with antioxidant levels in plant extracts as shown in Table 2 and 3. Other authors have shown a positive correlation between phenolic compounds and antioxidant activity of a plant extract on the one hand [3],[26],[27],[28] and between antioxidant activity and inhibition activity of $\alpha$-glucosidase on the other hand [3],[20]. Nguyen and al. 2019 had shown that extracts from the barks of Canarium tramdenum were more active on the radical $\mathrm{DPPH}^{\bullet}$ than the radical ABTS ${ }^{\bullet}$ with $\mathrm{IC}_{50}$ of $12.33 \mu \mathrm{g} / \mathrm{mL}$ and $47.87 \mu \mathrm{g} / \mathrm{mL}$ respectively [20]. The low antiradical activity on the cationic radical ABTS ${ }^{\bullet+}$ may be due to the presence of certain compounds in extracts that would absorb at the same wavelength as the radical. The literature tells us about the need to reduce the harmful effects of free radicals in the body. Indeed, reactive oxygen species such as the hydroxyl radical $\mathrm{OH}^{*}$, the superoxide anion $\mathrm{O}_{2}{ }^{*}$ and the nitrous oxide $\mathrm{NO}^{*}$ generate many pathophysiological disorders such as arthritis, inflammation, cancer and diabetes [29]. It has also been shown that diabetic patients are under oxidative stress. So an increased generation of free radicals and a lack of antioxidants can contribute to the beginning and progression of complications associated with diabetes [9]. One of the direct complications associated with diabetes is the onset of cancer. However, the use of antioxidants by diabetic patients is particularly important to prevent longterm complications that may occur. Based on the above, methanol extracts of Acacia macrostachya contain 
pharmacological molecules that could be used to prevent the occurrence of cancer in diabetics.

\section{CONCLUSION}

This study was focused on anti-diabetic and antiradical activities of Acacia macrostachya, traditionally used as medicinal plant in Burkina Faso against inflammation, cancer and oxidative stress. The obtained results highlighted the highly significant inhibitory effect against $\alpha$-glucosidase and antiradical activity that its root and stem barks possess. All these two properties are implicated in cancer prevention in diabetics. In our future investigations, we will focus on the bio-guided isolation of the anti-diabetic and antioxidant molecules of this plant.

\section{ACKNOWLEDGMENTS}

We thank the ISP (International Science Program) through ANEC (African Network of Electroanalytical Chemists) for giving us two mobilities in Europe.

\section{REFERENCES}

[1] Atlas du diabète de la Fédération Internationale de Diabète (FID). $6^{\text {ème }}$ édition, Bruxelles, Belgique. www.diabetesatlas. 2013.

[2] Sandrine NJ. Necessité et faisabilité de la decentralisation de la prise en charge des malades diabétiques à tous les niveaux de la pyramide sanitaire au Mali. Thèse de doctorat, Université de Bamako. 2008;119.

[3] Peyman S, Behvar A, Mohammad AE, Hossein D, Irag G. $\alpha$ Glucosidase and $\alpha$-amylase inhibitory effect and antioxidant activity of ten plant extracts traditionally used in Iran for diabetes. Journal of Medicinal Plants Research. 2013; 7 (6): 257-266.

[4] Sarwar N, Gao P, Seshasai SR, Gobin R, Kaptoge S, Di A et al. Diabetes mellitus, fasting blood glucose concentration, and risk of vascular disease: a collaborative meta-analysis of 102 prospective studies. Emerging Risk Factors Collaboration. Lancet. 2010; 26 (375): 2215-2222.

[5] Bourne RR, Stevens GA, White RA, Smith JL, Flaxman SR, Price H et al. Causes of vision loss worldwide, 1990-2010: a systematic analysis. Lancet Glob. Heal. 2013; 1: e339-e349.

[6] United States Renal Data System. National Institutes of Health, National Institute of Diabetes and Digestive and Kidney Diseases, Bethesda,MD. 2014 USRDS annual data report: Epidemiology of kidney disease in the United States. 2014; 188-210.

[7] Apostolidis E, Lee CM.. In vitro potential of Ascophyllum nodosum phenolic antioxidant-mediated $\alpha$-glucosidase and $\alpha$-amylase inhibition. Journal of Food Science. 2010; 75: 97-102.

[8] Tsujita T, Takaku T, Suzuki T. Chestnut astringent skin extract, an $\alpha-$ amylase inhibitor, retards carbohydrate absorption in rats and humans. Journal of Nutritional Science and Vitaminology. 2008; 54: 82-88.

[9] Jin L, Xue HY, Jin LJ, Li SY, Xu YP. Antioxidant and pancreasprotective effect of aucubin on rats with streptozotocin-induced diabetes. European Journal of Pharmacology. 2008; 582: 162-167.

[10] Iwai K. Antidiabetic and antioxidant effects of polyphenols in brown alga Ecklonia stolonifera in genetically diabetic KK-A(y) mice. Plant Foods Human Nutrition. 2008; 63: 63-169.

[11] Rapport de l'enquête nationale sur la prévalence des principaux facteurs de risques communs aux maladies non transmissibles au Burkina Faso. Enquête steps 13, Ouagadougou, Burkina Faso. 2014.

[12] Organisation mondiale de la Santé (OMS). Journée mondiale du diabète https://news.un.org/fr/story/2018/11/1029181, 14 novembre 2018

[13] Atlas du diabete de la Fédération Internationale du Diabète (FID), $9^{\text {ème }}$ édition, Busan, Corée du Sud. https://diabetesatlas.org/fr/sections/demographic-and-geographicoutline.html. 2019.

[14] Organisation Mondiale de la Santé (OMS), Génève, Suisse. Stratégie de l'OMS pour la Médecine Traditionnelle pour 2002-2005. WHO/EDM/TRM/2002.1, 2002

[15] Sawadogo WR, Maciuk A, Banzouzi JT, Champy P, Figadere B, Guissou IP and Nacoukma OG. Mutagenic effect, antioxidant and anticancer activities of six medicinal plants from Burkina Faso. Natural Products Research. 2012; 26 (6): 575-579.

[16] Guissou IP. Valorisation scientifique (pharmacochimie) des plantes médicinales du Burkina Faso: expérience de l'IRSS Commununication-symposium de la pharmacopée africaine de Bamako. 2002.

[17] Tondé I, Fofana S, Gnoula C, Palé E, Nébié RHC, Nikiema JB, Simpore $\mathrm{J}$ and Guissou IP. Antiplasmodial and DPPH radica scavenging effects in extracts from Acacia macrostachya (mimosaceae). World Journal for Pharmaceutical Research. 2016; 5 (8): 219-233.

[18] Tchoukoua A, Turibio KT, Narandulam U, Ken-ichi K, Eunsang K, Hiroyuki M, Takuya K, Yoshihito S and Bonaventure TN. New triterpene saponins from the roots of Acacia macrostachya (Mimosaceae). Bioscience, Biotechnology and Biochemistry. 2017; 81 (12): 2261-2267.

[19] Galvez L, Kwon Y, Apostolidis E and Shetty K. Phenolic compounds , antioxidant activity and in vitro inhibitory potential against key enzymes relevant for hyperglycemia and hypertension of commonly used medicinal plants, herbs and spices in Latin America. Bioresource Technology. 2010; 101 (12): 4676-4689.

[20] Nguyen VQ, Tran DX, Hoang-Dung T, Nguyen TDT, Le Thu T, Can $\mathrm{TH}$, Yusuf $\mathrm{A}$ and Phung TT. Antioxidant, $\alpha$-Amylase and $\alpha$ Glucosidase inhibitory Activities and Potential Constituents of Canarium tramdenum Bark. Molecules. 2019; 24 (605).

[21] Karim G, Christel T, Jaques P. Diabète et cancer: une association pernicieuse. Revue Medicale Suisse. 2010; 6: 1193-1198.

[22] Association Francophone des Soins Oncologiques de Support. Diabète et Cancer chez un patient adulte (hors hématologie). https://www.afsos.org/fiche-referentiel/diabete-cancer-chez-patientadulte-hematologie/, mise à jour du 14/12/2018.

[23] Huxley R, Ansary-Moghaddam A, Berrington de Gonzalez A, Barzi F. and Wooward M. Type II diabetes and pancreatic cancer: A metaanalysis of 36 studies. British Journal of Cancer. 2005; 92 (20): 76-83.

[24] Mitri J, Castillo J, Pittas AG. Diabetes and risk of non-Hodgkin's lymphoma: A meta-analysis of observation studies. Diabetes Care 2008; 31 (23): 91-97.

[25] Evans JM, Donnelly LA, Emslie-Smith AM, Alessi DR, Morris AD Metformin and reduced risk of cancer in diabetic patients. Diabetic Medicine. 2001; 18 (48): 03-08

[26] Sawadogo WR, Meda A, Lamien CE, Kiendrebeogo M, Guissou IP, Nacoulma OG. Phenolic Content and Antioxidant Activity of Six Acanthaceae from Burkina Faso. Journal of Biological Science. 2006; 6 (2): 249-252.

[27] Bajpai M, Mishra A and Prakash D. Antioxydant and free scavenging activities of some leafy vegetables. International Journal of Food Science and Nutrition. 2005; 56 (7): 473-481.

[28] Stratil P, Klejdus B and Kuban V. Determination of total content of phenolic compounds and their antioxidant activity in vegetableEvaluation of spectrophotometric methods. Journal of Agricultural and Food Chemistry. 2006; 54: 607-616.

[29] Mandal P, Misra TK, Ghosal M. Free-radical scavenging activity and phytochemical analysis in the leaf and stem of Drymaria diandra Blume. International Journal of Integrative Biology. 2009; 7: 80-84.

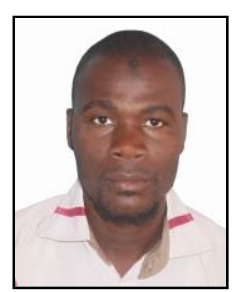

Hamidou Têeda GANAME was born in Koumbri, Burkina Faso (14 August 1989). He started his University studies in Science and Technology in 2011 at University Joseph KI-ZERBO, Ouagadougou, Burkina Faso. He obtained his Master degree in Organic chemistry/Natural Product in 2017. He currently prepares his $\mathrm{PhD}$ at the "Laboratoire de Chimie Analytique Environnementale et BioOrganique (LCAEBiO)", University Joseph KIZERBO, Burkina Faso. His research theme is about the bio-guided isolation of anticancer and antidiabetic compounds from natural products.

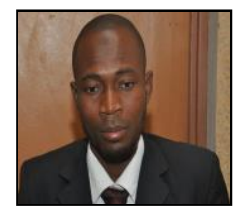

Dr. Yssouf KARANGA was born in Tipadipa, Ivory Coast (12 December 1986). He is currently Lecture in Chemistry at University Norbert ZONGO, Koudougou, Burkina Faso. His mean research interest includes natural products, analytical chemistry and biosensor development. He is Associate Professor in the Laboratoire de Chimie Analytique Environnementale et Bio-Organique (LCAEBiO), Université Joseph KIZERBO, Burkina Faso and affiliated to the Laboratoire de Chimie des Matériaux et de l'Environnement (LCME), Université Norbert ZONGO, Koudougou, Burkina Faso.

His publications: 
[1] Karanga Y, Ilboudo O, Bonzi S, Tapsoba I, Somda I and BonziCoulibaly YL. Phytochemical and Antifungal Properties of Euphorbia hirta $L$ against Fusarium moliniforme and Phoma sorghina. Natural Product Indian Journal. 2017;13 (1): 105.

[2] Foukmeniok SM, Ilboudo O, Karanga Y, Tapsoba I, Njanja E, Kenfack IT. Direct and simultaneous quantification of rutin and quercetin in natural fruits base on purified Arabic Gum modified carbon paste electrode. SN Applied Sciences. 2019; 1: 385.

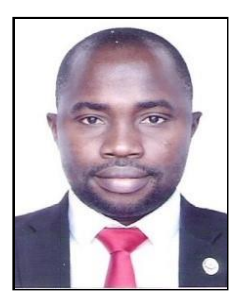

Dr. Ousmane ILBOUDO was born in Sassandra, Ivory Coast (17 july 1983). He is currently Lecture in Chemistry at University Joseph KI-ZERBO, Ouagadougou, Burkina Faso, where is teaching and conducting research project. He means research interest include natural products and analytical chemistry and has published many papers on related topic. He is affiliated to the "Laboratoire de Chimie Analytique Environnementale et Bio-Organique (LCAEBiO)", University Joseph KI-ZERBO,

Burkina Faso.

His publications:

[1] Foukmeniok SM, Ilboudo O, Karanga Y, Tapsoba I, Njanja E, Kenfack IT. Direct and simultaneous quantification of rutin and quercetin in natural fruits base on purified Arabic Gum modified carbon paste electrode. SN Applied Sciences. 2019; 1: 385.

[2] Ilboudo O, Bonzi S, Tapsoba I, Somda I, Bonzi-Coulibaly YL. In vitro antifungal activity of flavonoid diglycosides of Mentha piperita and their oxime derivatives against two cereals fungi. Compte Rendu Chimie 19. 2016; 857-862.

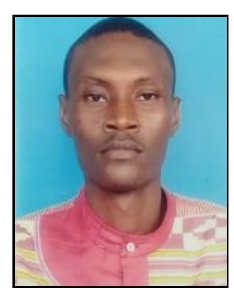

Wende-Konté Hazael Conania NIKIEMA was born in Ouagadougou, Burkina Faso (21 June 1993). $\mathrm{He}$ started his university studies in Science and Technology in 2013 at University Joseph KI-ZERBO, Ouagadougou, Burkina Faso. In 2020, he obtained his Master degree in Organic chemistry/Natural Product under supervision of Prof Issa TAPSOBA. He currently prepares his $\mathrm{PhD}$ in Natural products in the "Laboratoire de Chimie Analytique University Joseph KI-ZERBO, Burkina Faso.

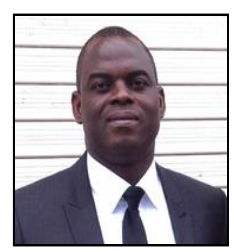

Dr. Richard Wamtinga SAWADOGO was born in Goupana, Burkina Faso (28 July 1972). He received his $\mathrm{PhD}$ in Biochemistry and phytochemistry from University Joseph KI-ZERBO, Burkina Faso in 2006. $\mathrm{He}$ is holding various posts as associate professor at Department of Pharmaceutical Sciences of University Joseph KI-ZERBO, senior researcher at Research institute of health sciences of Ouagadougou, associate editor of "Sciences et Techniques" and Academic Editor of "International Research Journal of Pure and Applied Chemistry". The main topic of his research is the evaluation of biological properties of natural products as anticancer, anti-inflammatory and antiepileptic drugs. He did his first postdoctoral position (2008-2009) at University of Paris-sud XI, in the laboratory of pharmacognosy (Faculty of pharmacy) under grant from "Agence Universitaire de la Francophonie". From 2011 to 2013 he was a postdoctoral researcher at "Laboratoire de Biologie Moleculaire et Cellulaire du Cancer (LBMCC)" in Luxembourg under grant from "FNRLuxembourg" and "Marie-Curie Actions" of European Union. From 01/2019 to 10/2019 he was a visiting scholar of American Fulbright program at the University of Chicago, School of Medicine. He evaluated the anticancer, anti-inflammatory, analgesic, antipyretic, antioxidant and antiepileptic effects of many plant extracts, fractions or isolated compounds and he published 36 papers (impact factor between1 to 4.7). He has got two Prizes in 2004, one from the President of Burkina Faso and the other from the Ministry of Health of Burkina Faso for the impact of his research results to solve a public health problem in this nation. From 2013 to 2018, he was the Head of the Unit of applied Biology at Institute of health sciences research and from 2014 - 2015, he was the General Director sectoral studies and statistics at Ministry of scientific research and innovation, Ouagadougou, Burkina Faso. Since 2015 he is the inspector general for the ministry of higher education, scientific research and innovation of Burkina Faso.

His publications:

[1] Sawadogo WR, Luo Y, Elkington B, He TC, Wang CZ, Yuan CS. Cytotoxicity and Preliminary Analysis of the Pro-apoptotic and Cell
Cycle Arrest Effets of Lantana ukambensis Against colorectal Cancer Cells International Journal of Applied Biology and Pharmaceutical. 2020; 11 (3): 170-187.

[2] Sawadogo WR, Cerella C, Al-Mourabit A Moriou, C, Teiten MH, Guissou IP, Dicato M and Diederich M. Cytotoxic, Antiproliferative and Pro-Apoptotic Effects of 5-Hydroxyl-6,7,31,41,51Pentamethoxyflavone Isolated from Lantana ukambensis. Nutrients. $2015 ;(7): 10388-10397$.

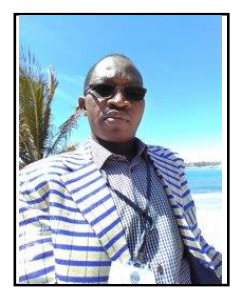

Dr. Issa TAPSOBA was born in Ouagadougou, Burkina Faso (24 January 1974). He received his PhD in organic electrochemistry from the faculty of sciences of Tunis El Manar University, Tunisia in 2004. He was in postdoctoral position from 2004 to 2007 at the "Ecole Normale Supérieure ULM de Paris', France under grant from "Agence Universitaire de la Francophonie (AUF) and a contract with LVMH". on the design of microfluidic devices for the continuous measurement of oxidative stress and monitoring of the differentiation of stem cells in microsystems. He has been received as visiting reseacher by the Professor LO Gorton at the Lund University, Sweden where he worked on the design of biosensors based on plant's enzyme immobilization for $\mathrm{H}_{2} \mathrm{O}_{2}$ and $\mathrm{NO}$ measurement. Since 2007, he was recruited as Lecture at the University Joseph KIZERBO, Burkina Faso in the department of chemistry where he is actually serving as Associate Professor. His main research activities deal with the isolation and identification of bioactive products from local plants and the development of analytical tools for the detection of pollutants. From 2013 to 2019 , he was the Director general of the scientific reseach and innovation at the Ministry of Higher Education, Scientific Research and Innovation of Burkina Faso. Currently he is the Director general of the Polytechnic School of Ouagadougou, the Executive Secretary of the African Network of Electroanalytical Chemists (ANEC) and the Head of the Analytical and environmental chemistry team in the "Laboratoire de Chimie Analytique Environnementale et Bio-Organique (LCAEBiO)', University Joseph KIZERBO.

His publications:

[1] Ilboudo O, Bonzi S, Tapsoba I, Somda I, Bonzi-Coulibaly YL. In vitro antifungal activity of flavonoid diglycosides of Mentha piperita and their oxime derivatives against two cereals fungi. Compte Rendu Chimie 19. 2016; 857-862.

[2] Karanga Y, Ilboudo O, Bonzi S, Tapsoba I, Somda I and BonziCoulibaly YL. Phytochemical and Antifungal Properties of Euphorbia hirta $L$ against Fusarium moliniforme and Phoma sorghina. Natural Product Indian Journal. 2017; 13 (1): 105.

[3] Tapsoba I, Arbault S, Walter P, Amatore C. Finding Out Egyptian Gods' Secret Using Analytical Chemistry: Biomedical Properties of Egyptian Black Makeup Revealed by Amperometry at Single Cells. Analytical Chemistry. 2010; 82: 457-460.

[4] Ferreira DCM, Tapsoba I, Arbault S, Bouret Y Suzana M, Moreira A, Pinto AV, Goulart MOF, Amatore C. Ex vivo activities of betalapachone and alpha-lapachone on macrophages: a quantitative pharmacological analysis based on amperometric monitoring of oxidative bursts by single cells. Chembiochem: a European Journal of Chemical Biology. 2009; 10 (3): 528-538 